\title{
Erratum to: Biosynthesis of caffeic acid in Escherichia coli using its endogenous hydroxylase complex
}

Yuheng $\operatorname{Lin}^{1}$ and Yajun Yan ${ }^{2 *}$

\section{Erratum to: Microbial Cell Factories 2012, 11:42 \\ DOI 10.1186/1475-2859-11-42}

Recently, we have noticed an accidental error existing in this article [1]. In the section Materials and Methods "Construction of Plasmids", we mistakenly described that "the gene cluster hpaBC was amplified from $\boldsymbol{E}$. coli MG1655 genome". This information should be corrected as "the gene cluster $h p a B C$ was amplified from $\boldsymbol{E}$. coli BL21 (DE3) genome". This change will in no manner affect the outcome/interpretation of the experiments as described in the original publication and will not affect the merit of this work. The authors apologize for any inconvenience caused thereof.

\section{Author details}

1 Department of Biological and Agricultural Engineering, the University of Georgia, Athens, GA 30602, USA. ${ }^{2}$ Biochemical Engineering Program, Faculty of Engineering, the University of Georgia, Athens, GA 30602, USA.

The online version of the original article can be found under doi:10.1186/1475-2859-11-42.

Received: 13 July 2015 Accepted: 13 July 2015

Published online: 30 July 2015

\footnotetext{
Reference

1. Lin Y, Yan Y (2012) Biosynthesis of caffeic acid in Escherichia coli using its endogenous hydroxylase complex. Microb Cell Fact 11:42.
}

\footnotetext{
*Correspondence: yajunyan@uga.edu

${ }^{2}$ Biochemical Engineering Program, Faculty of Engineering, the University

of Georgia, Athens, GA 30602, USA

Full list of author information is available at the end of the article
} 